\title{
Review on the Research Status of International Exchanges and Cooperation of Private Universities in China
}

\author{
Mei-Ling GUO ${ }^{1, a}$, Shui-Ping HUANG ${ }^{2, b,{ }^{*}}$ \\ Guangdong University of Science \& Technology, Dongguan, Guangdong Province, China \\ awmcxks07@126.com, bhsp0121@126.com \\ ${ }^{*}$ Corresponding author
}

\begin{abstract}
Keywords: Review, Research Status, International Exchanges and Cooperation, Private Universities.
\end{abstract}

\begin{abstract}
International exchanges and cooperation of private universities is an important part of higher education international exchanges and cooperation. As there is no overall and systematic research yet on international exchanges and cooperation of private universities, it is necessary to conduct an overall and systematic research on it from the perspective of theory and solid evidence. Before carrying out the research, literature review on the research status of international exchanges and cooperation of private universities should be done clearly at first.
\end{abstract}

\section{Introduction}

Since the reform and opening up, Chinese private higher education has got rapid development, from nothing to something and big to strong. By 2015, there are a total of 2,852 general institutes of higher education and adult schools of higher education, among which there are 2,560 general institutes of higher education and 26.253 million students at school. The number of private university is 734 (including 275 independent colleges) in 2015, increased from 21 in the year 1996, holding 28.67\% of the total number of general institutes of higher education. And the number of students at private universities is 6.109 million, accounting for $23.27 \%$ of the total number of students at general institutes of higher education, among which there are 509 postgraduates, 3.8333 million undergraduates and 2.2752 million college students.[1] Private universities have become an important component of Chinese higher education.

More than 30 years practice on international exchanges and cooperation of Chinese private universities has proven that the development of international exchanges and cooperation can effectively improve private universities' strength in running schools. International exchanges and cooperation of private universities is an important part of higher education international exchanges and cooperation. Chinese scholars' research on internationalization of higher education is mainly about international exchanges and cooperation of public universities and Chinese-foreign cooperation in running schools. Therefore, there is no overall and systematic research yet on international exchange and cooperation of private universities with a lack of theory research and solid evidence data.

In consideration of the importance of international exchanges and cooperation to the development of private universities and the lack of research on international exchanges and cooperation of private universities, it is necessary to conduct an overall and systematic research on international exchanges and cooperation of Chinese private universities from the perspective of theory and solid evidence, to provide reference and instruction for numerous private universities to develop international exchanges and cooperation. Before carrying out the research, literature review on the research status of international exchanges and cooperation of private universities should be done clearly at first.

\section{Domestic Researches}

Based on the data retrieval in CNKI, it can be found out that over 100 articles on international exchanges and cooperation of education have been published. From the perspective of published date, 
in late 1980s few articles are published. Not until 1990's does the study appear more. Until 21st century, especially after 2002, more and more studies are conducted. To conclude, studies on international exchanges and cooperation of education are conducted on the following aspects:

a) Background, motives and current research on international exchanges and cooperation of education. Under profound era background, international exchanges and cooperation of education becomes the key component of exchanges among countries. In the articles like, Introduction to Comparative Education: Education and National Development (co-wrote by Mingyuan Gu \& Liyin Xue)[2], Research on Chinese Policy in External Education (wrote by Yanqiao Jiang)[3], International Exchange of Education: Challenges and Responses (wrote by Min Li)[4], Educational Input and Output Under the Framework of WTO \& Educational Legislation and Policy Adjustment by Chinese Government (wrote by Mansheng Zhou)[5], different authors did studies on China's education exchanges policies in different periods from different perspectives. The motive of international exchanges and cooperation of education is always one research interests of most scholars. Many scholars analyze the motives behind specific forms of international exchanges and cooperation. For example, Hui Yang analyzes consumers' need for Chinese-Foreign Cooperation in Running Schools from the perspective of educational economics in Market Supply and Chinese-Foreign Cooperation in Running Schools [6] JianXin Gu analyzes factors of transnational education in different levels in the framework of Push-pull Theory in The Development Idea and Strategy of Transnational Education. Researchers acknowledge widely that opening and reform under the economy globalization is the external factors promoting the international exchange and cooperation of China's higher education. Chunhong Li points out that China have solved many problems existed in education and economic development through educational exchanges and cooperation in Review on the Open-up Process of China's Education Since 1980s. Mei Li proposes that the imbalance between export and import of China's educational exchange marks China as a top education import country in the world and weak education export country in The International Market for Higher Education: the Global Flow of Chinese Students.

b) Usages and Functions of international exchanges and cooperation of universities and colleges. Changgui Chen claims that except for nurturing talents, conducting scientific research and serving society, universities and colleges have the fourth function, international cooperation in International Cooperation: The Fourth Function of Higher Education. Yuguang Tang proposes the same idea in Internationalization: A New Function of University in the Era of Knowledge Economy.[7] Guangbin Shen shows disagreement on this idea and holds that international cooperation is an inevitable choice for universities and colleges under the trend of internationalization of higher education, and a way of completing their missions for universities and colleges in Comment on "International Cooperation: The Fourth Function of Higher Education". [8]

c) Studies on forms of international exchanges and cooperation of higher education. Scholars conduct plentiful studies on this aspect and most of them engage in international exchanges and cooperation. Most studies focus on a case study of an individual university, particularly the research-oriented university, and the research targets are mostly contents, channels, modes, measures and strategies of international exchanges and cooperation of higher education. Some studies expand the research field to a certain region, like that some scholars have conducted survey on international exchanges and cooperation of universities in Shanghai, and proposed that different levels of higher education face some common problems and different types of higher education have their own specific problems. Meanwhile, they point out that imbalanced development, limited educational level of foreign student, objective environment like language and cultural difference, funds and capacities of universities are obstacles faced with and difficult to overcome in short term [9]. Some studies hold that two features, regional imbalances and imbalances among different types of higher education, exist in the overall international exchanges and cooperation of China's higher education [10]

d) Studies on the evaluation index of internationalization of universities. In recent decades, evaluation index of internationalization of universities gradually become a hot point of studies. In The Evaluation Index System of Internationalization of Universities [11] Shengbing Li constructs a 
evaluation index system containing 7 first-class indexes and 18 second-class indexes. Scholars like Changgui Chen conduct surveys on internationalization of 26 research-oriented universities in China and further put forward five indexes indicating internationalization of research-oriented universities: strategic planning and organizing structures, staff structures and exchanges, teaching and scientific research, related conditions and facilities, and achievements exchange [12]

e) Studies on different fields of international exchanges and cooperation of higher education. In the diversified fields of international exchanges and cooperation of higher education, transnational or cross-border education is the most frequently discussed research topic. Studies on such aspect spring up like mushrooms, including articles on journals, thesis of masters and doctors, monographs, covering early introduction of research experiences, analysis of research questions and theoretical exploration.

Scholars like Mansheng Zhou, Minxuan Zhang, Xiaozhou Xu, have conducted long-term and in-depth study on cross-border education. Jianbo Wang's Transnational Higher Education Theory and its Practice in China is the first doctoral thesis on cross-border education. In addition, many scholars have carried out effective research on quality guarantee of Chinese-foreign cooperation in running schools, public-sponsored oversea study, interschool student exchange, introducing foreign intelligence, and studying in China, etc, which profoundly reveal the history, features, rules and problems of a certain field of higher education's international exchanges and cooperation.

f) Studies on international exchanges and cooperation problems. China's educational international exchanges and cooperation flourishes after the open-up and reform, makes great achievements and also have many spaces needed to improve. Some scholars conclude: Firstly, the capabilities, scale and benefits of international exchanges and cooperation fall behind; Secondly, the quality and scale of international exchanges and cooperation needs improvement; Thirdly, there needs a strategic thinking on the significance of international exchanges and cooperation.[13] Guofu Liu, in A Rational Review and Legal Thinking on China's Policy of Studying Abroad in the Last Thirty Years, points out that the unrevealing of information is an apparent problem exists in China's international exchanges and cooperation.

g) Studies on international exchange and cooperation of China's Private Universities. After 2010, near 10 articles on international exchanges and cooperation of China's Private Universities have been published in Chinese Academy Journal. Chao Lin analyzes the main problems private schools faced with on educational exchanges and proposes the methods and strategies of coordinating with international education under the constantly developing trend in Problems and Strategies of International Exchange and Cooperation in Private Colleges.[14] Li Chen in Problems and Suggestions of the Development of Chinese-Foreign Cooperation in Running Schools in Private Higher Education, [15] and Yuan Hu in On Countermeasures for Chinese-Foreign Cooperation in Running Schools of Private Universities, explore the problems and countermeasures for Chinese-foreign cooperation in running schools of private universities. Guangjie $\mathrm{Xu}$, in An Effective Way to Develop International Exchanges and Cooperation in Private Colleges: Taking East University of Heilongjiang as an Example,[16] and Dequn Zhang, in Exploration of Internationalization of Private Higher Education: Taking Shanghai Institute of Visual Arts as an Example,[17] do case studies on the international exchanges and cooperation of the above two schools. Yong Jia, On the Development of Graduate Education in Private Universities in the United States and Its Enlightenment to Private Colleges and Universities in China [18] discusses the enlightenment of graduate education in private universities in the United States to that of private colleges and universities in China. Currently, Scholars in China have conducted no in-depth studies on international exchanges and cooperation of private colleges and universities in China and no well-known experts have systematically and comprehensively studied the concepts, modes, strategies and other issues of international exchanges and cooperation of private colleges and universities in China. 


\section{Oversea Researches}

With the deepening globalization, the educational internationalization has become increasingly important and relevant researches are rich.

a) Researches about the relationship between globalization and higher education internationalization. In 1980, Clark Kerr (Chairman, Carnegie Higher Education Policy Council) noted that we are in need of a new higher education concept exceeding the land-grant colleges, which actually means that higher education should be open to the whole world, in other words, higher education should be international.[19] Altbach P.G. believed that globalization has a greater impact on colleges and universities in 21 century and all aspects like policy and its situation have been influenced by the trend of globalization.[20] Peter S. analyzed the unavoidable effects of globalization on higher education through three ways.[21] Knight J. made a further summary of the impacts of globalization trend on higher education. [22]

b) Researches about the standards of universities internationalization. 1986, Kitamura, a famous Japanese educator, put forward three standards to measure the internationalization level of universities, namely versatility, communicative, openness. The American Council on Education applies four indexes: support from institutions, curriculum and extra-curriculum activities, staff policies and opportunities, international students. The International of Higher Education in the United States, Britain and Australia, co-wrote by Zeng M.C., Wang M.X. \& Lin L., studied several research universities in USA, UK and Australia and illustrated how internationalization have been applied within universities. [23]

c) Main researchers of relevant fields. There are several influential scholars in international exchanges of higher education. Altbach P.G. (Boston College, USA) mentioned in his Globalization and the University: Realities in an Unequal World that globalization has influenced universities in developing countries.[24] And in Higher Education Crosses Borders, he used Push-Pull theory analyzing the reasons and motivations of international students from developing countries.[25] In Higher Education's Landscape of Internationalization: Motivations and Realities (co-wrote with Knight J.), Altbach P.G. suggested that international educational exchanges activities within universities have greatly exceeded two decades ago in terms of scale, scope, and complexity and universities in different countries have various motivations towards international education.[26]

Knight J., from University of Toronto, Canada proposed the most widely accepted definition of higher education internationalization, which is "a process to integrated teaching, research and service with internationalization and intercultural communication within higher education institutions".[27] In Internationalization Brings Important Benefits as Well as Risks, Knight J. analyzed that an international research report of International Alliance of Universities. The report showed that the top three risks from international education are: commercialization of educational programs, diploma mills and the brain drain [28]

Knight J. addressed great importance on cross-countries education and has published a serial relevant articles such as Cross-Border Education: Not just Students on the Move [29] New Rationale Driving Internationalization [30] Transnational and Cross-Border Education: Definition and Data Dilemmas [31] etc. Hans de Wit from University of Amsterdam is also a well-known educator in this area and he noted in Strategies for Internationalization of Higher Education that internationalization motivation could be understood through four aspects which are culturally, politically, economically and academically [32] On the basis of Keller's academic strategies, John L. Davies puts forwards a concept frame for analyzing internationalization of universities [33]

\section{Comments of Current Research}

a) Currently, researches of internationalization of higher education not only include illustration of theories and concepts, comparative researches and comprehensive narration but also analysis of structures of frames, deep analysis of single cases and detailed research statistics. Relatively, they are 
deeper and wider than the domestic researches. However, there are few studies about the international education in private universities in China.

b) There are three main types of research in China: first one is based on some specific single university and the second one is general discussion of theories and the third one is about some certain area of higher education internationalization. The actual experiences from single cases study are mainly in state-owned research-universities and are about brief introduction and rarely have been deepened into theory studies. These theories discussion are about the state macro policy without considering practice.

The second type is relatively comprehensive including education policy, studying abroad and studying in China etc. But international exchange programs at a university usually include various areas as a system and current research about this is quite insufficient, among which has two major features: focusing on certain programs and populations (international students) while lack of all-around study of international exchanges and communications; mainly about research-universities and state-owned universities with few study about private higher institutions.

To sum up, it is possibly necessary to discuss and illustrate the relationship between private universities and international cooperation from a concept, model and strategy perspective.

\section{Acknowledgement}

This thesis is the research fruit of provincial key Project -A Study on Chinese-foreign Cooperation in Running Schools and its Developing Strategies in Guangdong Province (Project Number: GDJY-2015-C-a004) which is initiated by Guangdong Education Institute.

\section{References}

[1]Ministry of Education of the People's Republic of China, Statistical Bulletin of the National Education Development in 2015, http://www.moe.gov.cn.

[2]Mingyuan $\mathrm{Gu} \&$ Liyin Xue, Introduction to Comparative Education: Education and National Development, People's Education Press, 1996.

[3] Yanqiao Jiang, Research on Chinese Policy in External Education, East China Normal University, 2008.

[4] Min Li, International Exchanges of Education: Challenges and Responses, East China Normal University, 2008.

[5]Mansheng Zhou, Educational Input and Output under the Framework of WTO \& Educational Legislation and Policy Adjustment by Chinese Government, Journal of Jimei University, 2006(6).

[6] Hui Yang, Market Supply and Chinese-Foreign Cooperation in Running Schools, Education Science, 2003(6).

[7]Yuguang Tang, Internationalization: A New Function of University in the Era of Knowledge Economy, Teacher Education Research, 2000(5).

[8]Guangbin Shen, Comment on "International Cooperation: The Fourth Function of Higher Education”, Jiangsu Higher Education, 2000(6).

[9] Wenle Yan, A Study on the Problems and Countermeasures of International Communication and Cooperation of Shanghai’s Universities, Shanghai Normal University, 2006.

[10]Lu Wang \& Yunliang Cao, Analysis on the Characteristics and Problems of the Internationalization of Higher Education in Guangdong, Exploration of Higher Education, 2006(2).

[11] Shengbing Li, The Evaluation Index System of Internationalization of Universities, Journal of South China Normal University (Social Science Edition), 2005(12). 
[12] Changgui Chen, Internationalization Investigation and Evaluation Index Construction of Chinese Research Universities, Peking University Education Review, 2009(10).

[13] Xin Tong, Strategic Study on the Internationalization of China's Higher Education: Taking the Typical Example of Shanghai Jiao Tong University, Journal of Technology College Education, 2008(10).

[14]Chao lin, Problems and Strategies of International Exchanges and Cooperation in Private Colleges, Scientific Chinese, 2016(18).

[15] Li Chen, Problems and Suggestions of the Development of Chinese-Foreign Cooperation in Running Schools in Private Higher Education, Journal of Huanghe S\&T University, 2011(5).

[16] Guangjie Xu, An Effective Way to Develop International Exchange and Cooperation in Private Colleges: Taking East University of Heilongjiang as an Example, Northern Economy and Trade, 2016(8).

[17] Dequn Zhang, Exploration of Internationalization of Private Higher Education: Taking Shanghai Institute of Visual Arts as an Example, The Science Education Article Collects, 2015(9).

[18] Yong Jia, On the Development of Graduate Education in Private Universities in the United States and Its Enlightenment to Private Colleges and Universities in China, Net World, 2013(9).

[19] Xuefei Chen, On the Contemporary Ideas of American Higher Education, Liaoning Normal University Press, 1996.

[20] Altbach P. G., Globalization and the University: Realities in an Unequal World, International Handbook of Higher Education, 2006.

[21] Peter S., Globalization and Higher Education: Challenges for the 21st Century, Journal to Studies in International Education, 2006.

[22] Knight J., Internationalization: Concepts, Complexities and Challenges, International Handbook of Higher Education, 2006.

[23] Manchao Zeng, Meixin Wang \& Le Lin, The Internationalization of Higher Education in the United States, Britain and Australia, Peking University Education Review, 2009(4).

[24] Altbach P. G., Globalization and the University: Realities in an Unequal World, Tradition and Transition: The International Imperative in Higher Education, 2008.

[25] Altbach P. G., Higher Education Crosses Borders, Change, 2004.

[26] Altbach P. G., Higher Education's Landscape of Internationalization: Motivations and Realities, Tradition and Transition: The International Imperative in Higher Education, 2008.

[27] Knight J., Internationalization: Elements and Checkpoints, Research Monograph, 1994.

[28] Knight J., Internationalization Brings Important Benefits as Well as Risks, International Educator, 2007.

[29] Knight J., Cross-Border Education: Not just Students on the Move, International Educator, 2006.

[30] Knight J. New Rationale Driving Internationalization, International Higher Education, 2005.

[31]Knight J., Transnational and Cross-Border Education: Definition and Data Dilemmas, www.obhe.ac.uk.

[32] Hans de Wit., Strategies for Internationalization of Higher Education, A Comparative Study of Australia, 1995. 
[33] John L. Davies., Issues in the Development of Universities' Strategies for Internationalization, www.ipv.pt/millenium/davies11.htm. 